\title{
THE REVISION OF HISTORICAL AND CURRENT DISTRIBUTION OF HORDEUM GENICULATUM ALL. (POACEAE) IN SLOVAKIA
}

\author{
Daniel DÍTĚ ${ }^{1}$, Pavol ELIÁŠ jun. ${ }^{2}$ \& Vít GRULICH ${ }^{3}$
}

\begin{abstract}
Historical and current occurrence of halophytic-ruderal species Hordeum geniculatum was studied in Slovakia during 2003 - 2010. The species occurred only in the Podunajská nížina Lowland, where 16 sites were found in total including historical and recent locations. Recently, the number of sites decreased markedly and we confirmed only four localities. Due to the sharp decrease in the number of sites and proper habitats, Hordeum geniculatum is re-evaluated as endangered (EN) plant of Slovak flora.
\end{abstract}

Key words: occurrence, halophytes, Hordeum geniculatum, IUCN criteria.

Izvleček

Včlanku smo obravnavali historično in trenutno razširjenost halofitsko-ruderalne vrste Hordeum geniculatum na Slovaškem med leti 2003-2010. Vrsta se pojavlja le v nižini Podunajská nížina, kjer smo našli 16 lokalitet, vključno historičnih in recentnih. $\mathrm{V}$ zadnjem času je število rastišč zelo upadlo in potrdili smo samo štiri lokalitete. Zaradi močnega zmanjšanja števila lokalitet in primernih rastišč, predlagamo da se vrsta Hordeum geniculatum v flori Slovaške obravnava kot ogrožena (EN).

Ključne besede: pojavljanje, halofiti, Hordeum geniculatum, IUCN kriterij.

\section{INTRODUCTION}

Hordeum geniculatum All. [syn. Hordeum hystrix Roth, Hordeum marinum Huds. var. gussoneanum (Parl.) Thell., Hordeum marinum Huds. subsp. gussoneanum (Parl.) K. Richt., Hordeum winckleri Hack.] (Figure 1) belongs to the group of vanishing halophytic plants at the edges of its distribution range especially in the Pannonian Plain. It is included in the Red lists of endangered taxa in Austria, Croatia and Slovakia (Niklfeld \& Schratt-Ehrendorfer 1999, Feráková et al. 2001, Nikolić \& Topić 2004), while in Hun- gary, Romania and Serbia is not considered endangered (Oltean et al. 1994, Stevanović et al. 2006, Király 2007).

Hordeum geniculatum is distributed in large, partially disjunctive, Eurasian area: it occurs from the Iberian Peninsula, southern and southeastern Europe through the Middle East (Israel, Syria, Lebanon, Jordan, Turkey) to Central Asia. Native occurrence of the species was also mentioned for the North Africa (Morocco and Tunisia). As an alien species, $H$. geniculatum was found in Algeria, Libya and Egypt as well as the western part of North America (Conert 1998).

\footnotetext{
${ }^{1}$ Institute of Botany, Slovak Academy of Sciences, Dúbravská cesta 9, SK-845 23, Bratislava, Slovakia, daniel.dite@) savba.sk

${ }^{2}$ Department of Botany, Slovak University of Agriculture, Tr. A. Hlinku 2, SK-949 76 Nitra, Slovakia, pelias@afnet. uniag.sk

${ }^{3}$ Institute of Botany and Zoology, Masaryk University, Kotlářská 2, CZ-61137 Brno, Czech Republic, grulich@sci. muni.cz
} 


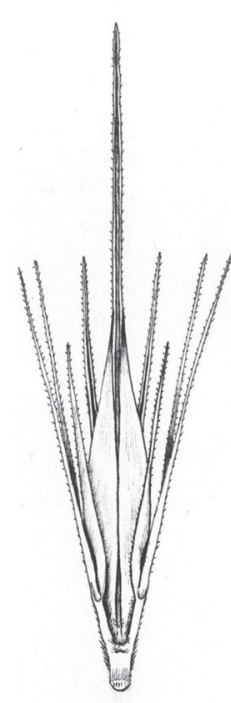

A

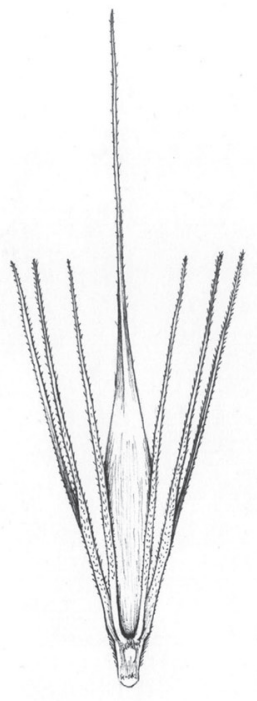

B

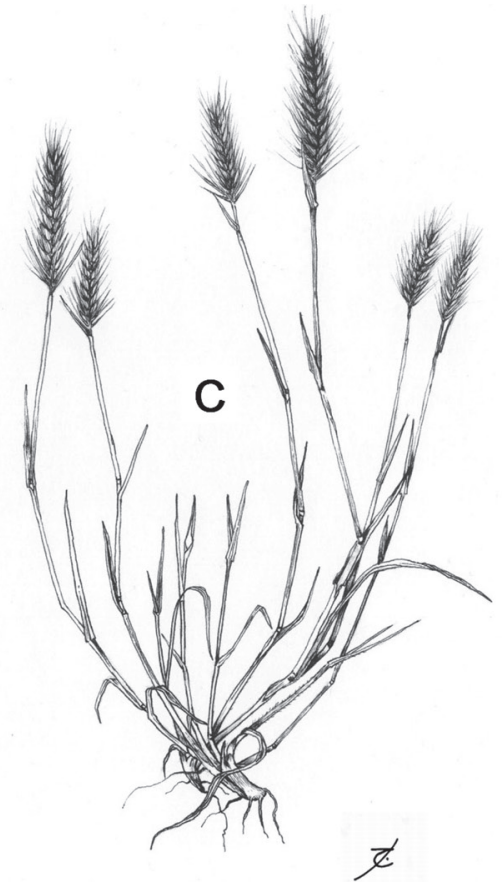

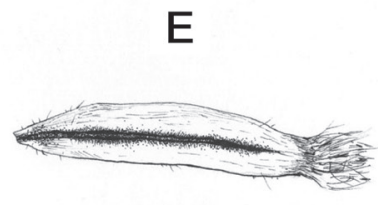

Figure 1: A - detail of underside of spikelet, B - detail of top side of spikelet, C - growth habit of Hordeum geniculatum, D - side view to spikelet, E - caryopsis (drawings Renata Grošaftová, 2011).

Slika 1: A - podroben prikaz spodnje strani klaska, B - podroben prikaz zgornje strani klaska, C - habitus vrste Hordeum geniculatum, D - stranski prikaz klaska, E - golec (slika Renata Grošaftová, 2011).

In central Europe, $H$. geniculatum is widespread from the Pannonian Lowland (Austria, Slovakia, and Hungary) to Ukraine, Moldova and the European part of Russia (Conert 1998, Grulich \& Maglocký 1999, Fischer et al. 2005).

The species prefers solonetz soils usually with low or moderate salt content, however, it can be also found in highly salinized soils, such as solonchaks, and thus appears in different halophytic and subhalophytic plant communities. Hordeum geniculatum has optimal conditions for its growth within the association Hordeetum hystricis Wendelbg. 1943. According to Mucina (1993), the association is considered as the most zoo-anthropogenic community of solonetz soils. The association is developed as the degraded stage of the halophytic communities Puccinellietum limosae Soó 1933, Achilleo setaceae-Festucetum pseudovinae Soó (1933) 1947 corr. Borhidi 1996 and Artemisio santonici-Festucetum pseudovinae Soó in Máthé 1933 corr. Borhidi 1996. It occurs usually in strongly grazed areas, especially near intensively trampled sites as watering places and animal paths. In optimum conditions, a dominance of Hordeum geniculatum in this community reached up to $75-80 \%$ (Wendelberger 1950, Dítě \& Eliáš jun. 2011 ined.). The ass. Hordeetum hystricis has centre of its distribution in Pannonia. It has been reliably documented in Austria, Slovakia, Hungary, Serbia and Romania (Wendelberger 1950, Vicherek 1973). The current main distribution area includes the eastern Hungarian alkali steppes in the Alföld region (Borhidi 2003), northern Serbia (Vojvodina) and western Romania (Dítě, Eliáš jun. \& Melečková 2011 ined.). Outside the area of the Pannonian Basin, the community has been recorded in southern and northeastern Romania (Pop 2002, Popescu 2005) and recently also at the Middle Danube Plain in Bulgaria (Tzonev et al. 2009).

Except within the ass. Hordeetum hystricis, Hordeum geniculatum was infrequently found in the association Camphorosmetum annuae Rapaics ex Soó 1933 (Dítě et al. 2008), Pholiuro pannonici-Plantaginetum tenuiflorae Wendelberger 1943 (Dítě et al. 2010), Puccinellion limosae Soó 1933 (Dítě et al. 2009) and some others communities. However, the occurrence of the species there was only occasional and with abundance not over $5 \%$.

The paper is aimed to obtain historical and current occurrence of Hordeum geniculatum in Slovakia as well as it reassesses the current IUCN Red List status of the species. 


\section{MATERIAL AND METHODS}

The study was carried out during the years 2003 2010 in the Podunajská nížina Lowland. The data concerning the distribution of the species were achieved from herbaria BP, BRA, BRNU, BRNM, LTM, MMI, MZ, NI, KO, OLM, PMK, PR, PRC, $\mathrm{SAV}, \mathrm{SLO}, \mathrm{ZV}$, literature and during our field research, as well. All data on the occurrence of $H$. geniculatum were divided into three groups: the first includes all the historical data from the literature and herbaria to year 1975, the second group includes historical data from literature and herbaria for the period of intensive land reclamation and drainage projects in the years 1975 - 1999, the third group includes current relevant data found after 2000. Results of this study are presented on the Figure 2 . The figure was designed by program ArcGis 9.2. Coordinates of historical localities were taken from Google Earth. Coordinates of recent localities were obtained during field research using GPS equipment Garmin CS 60.
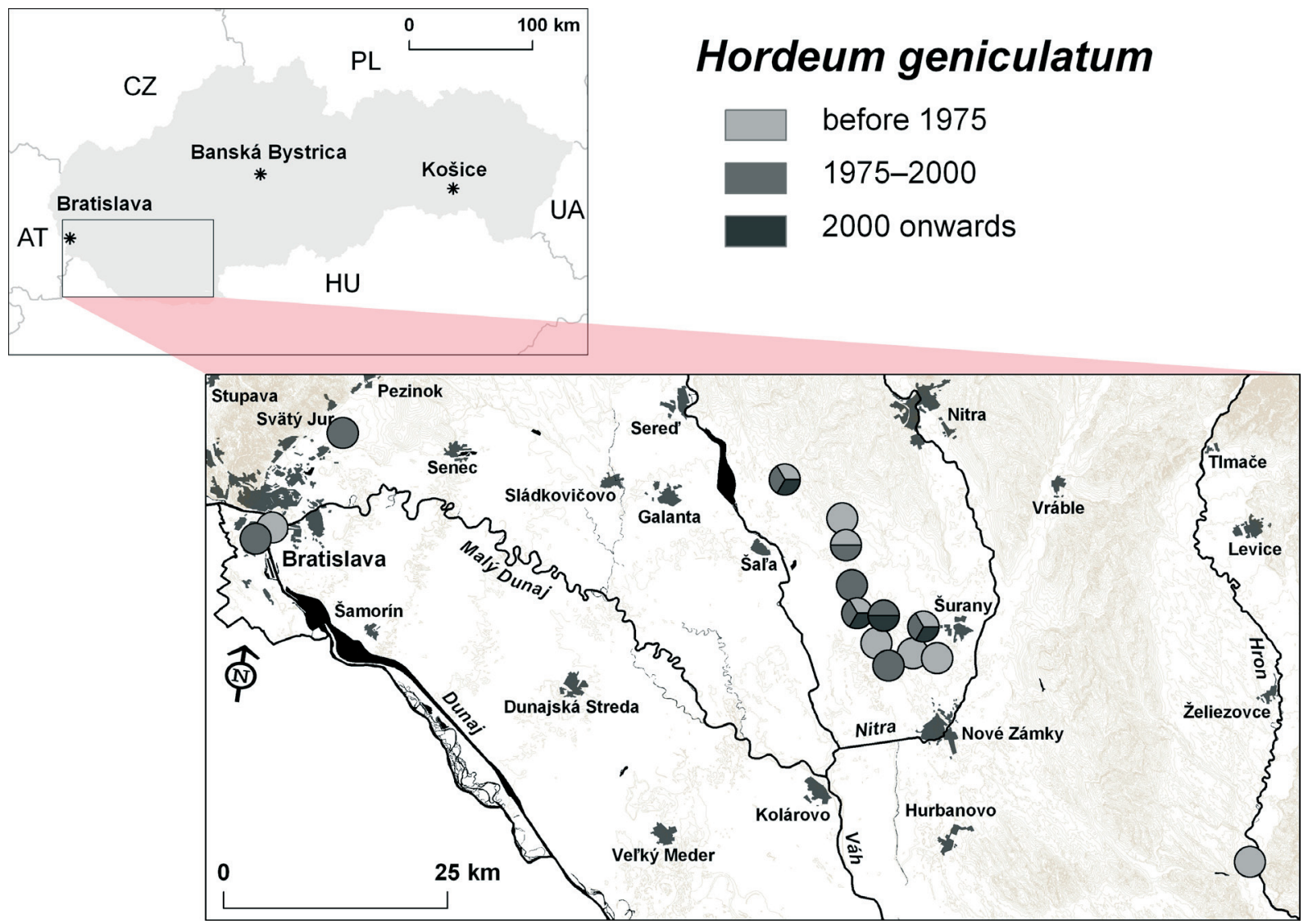

Figure 2: Historical and current distribution of Hordeum geniculatum in Slovakia.

Slika 2: Historična in trentna razširjenost vrste Hordeum geniculatum na Slovaškem.
Herbarium abbreviations are according to Holmgren et al. (1990) and Vozárová \& Sutorý (1980) are also used. Nomenclature of vascular plants follows Marhold \& Hindák (1998) and the names of syntaxa are according to Molnár \& Borhidi (2003).

\section{RESULTS}

In Slovakia, the occurrence of the species Hordeum geniculatum was recorded only in the Podunajská nížina Lowland. In total, approximately 16 localities were found (Figure 2). The exact number of localities could not be determined because some authors did not provide precise description of them. Before 1975, Hordeum geniculatum was confirmed here on 11 localities. Almost the same number of sites was also recorded between years 1975-1999; the species was confirmed in 9 locations. In this time, the occurrence of the species was also spo-

\section{Hordeum geniculatum}

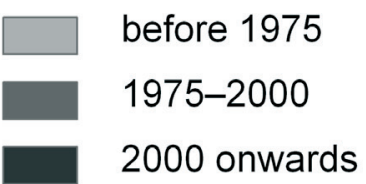
(2001). Phytogeographical divisions of Futák 
radically documented on ruderal places around Bratislava (town parts Háje and Ovsište) out of saline soils (see Appendix). Recently, we confirmed remnants of Hordeum geniculatum populations only at four sites. We present short description of all surviving recent populations:

\section{Tvrdošovce}

Several small populations were recorded around the village in the past (see Appendix). Recently, we have confirmed only two. The first population was discovered on a private pasture occupying an area about $50 \mathrm{~m}^{2}$. Between years $2003-$ 2005 , the species created here typical association Hordeetum hystricis. Community was maintained by grazing of small herd of goats. In 2009, we have not recorded grazing goats, causing a reduction in the area of population and disappearance of the above mentioned community. The micropopulation probably disappears in the coming years if grazing will be not restored.

The second micro-population was confirmed near the Ráczovo jazierko pond in the village. In the last three years (2009-2011), we also recorded relatively rich occurrence of Hordeum geniculatum, which has been caused due to the renewal of grazing on the locality (10 sheep).

\section{Šurany - Akomáň farmstead}

Hordeum geniculatum was found there first time by Krist (1940). In the late eighties of the last century, the species still created large stands (Ulrych 2009 in verb.). The population has been dramatically reduced when grazing was terminated. In 2002 , only residual population were confirmed on cart-road at the edge of saline pastures (up to 100 individuals) (Sádovský 2003). Currently, we have confirmed the occurrence of the species in an intensively overgrazed pasture near the farm buildings occupying area about $100 \mathrm{~m}^{2}$.

\section{Močenok - Siky farmstead}

The species was recorded there for first time in thirties of the 20th century (Valenta 1932 BRA). Currently, there is the most vital and most comprehensively known population in Slovakia containing thousands of individuals and covering area ca 2 hectares. It is also the single current location of association Hordeetum hystricis in the Podunajská nížina Lowland and Slovakia, respectively. The species occurred here on the intensive grazed sheep pasture near the farm buildings. Survival of the species and the community is existentially dependent on the current use of the site by sheep grazing.

\section{Horná Král'ová}

The occurrence of the species had been recorded at this location until 2009. The place is located about $2 \mathrm{~km}$ southwest of the village near a small pond. Small scale population of a few tens individuals occupied the rest of degraded saline habitat dominated by Tripolium pannonicum. The abandonment of grazing (or any management) has caused the expansion of ruderal (Atriplex tatarica, Echinochloa crus-gali, Elytrigia repens) as well as grassland species (Arrhenatherum elatius, Galium verum) in these stand. Hordeum geniculatum is there under acute threat of extinction.

\section{DISCUSSION}

Hordeum geniculatum is considered as a phytogeographically important border element of the Slovak flora - the Podunajská nížina Lowland is the northernmost part of the distribution range of the species (Grulich \& Maglocký 1999). The species was here firstly documented in 1923 (see Appendix). Most of Hordeum geniculatum localities were published by Krist (1940). The author found 11 localities between the towns of Nitra and Nové Zámky (see Appendix). These sites were mentioned much later by Grulich \& Maglocký (1999), the authors also confirmed presence of the species in six localities (Močenok, Jatov - Čierny Vŕšok, Tvrdošovce, Palárikovo, Akomáň farmstead and Čierna Voda village near Bratislava). In addition, particular data were published in some floristic and phytosociological works, in some cases including also phytosociological relevés (e.g. Vicherek 1973, Svobodová \& Řehořek 1985, 1992, Trávníček 1996, Sádovský 2003). General data of species occurrence in the territory between the lower Váh River and lower Nitra River was published by Dostál \& Červenka (1992).

Our results showed that the species was relatively frequent in former times; we found 16 localities in total (see Figure 2). Before 1975, the species occurred at 11 localities where intensive grazing was performed (Krist 1940, Vicherek 1973). In the next period $1975-1999$, nine localities of the species were found and number of Hordeum geniculatum localities decreased only slightly despite intensive meliorations, afforestation and transformation of saline habitats to arable land in 
those years. Meliorations practices usually consisted of drainage of large area which caused a gradual desalination of saline soils. So, obligate halophytes have lost one of the most important competitive advantages against other plants. Therefore, ruderal and meadow plant species started to replace them on these sites (Sádovský et al. 2004, Fehér 2007). In this period, occurrence of many halophytic species as Acorellus pannonicus, Camphorosma annua and Pholiurus pannonicus decreased or disappeared due to above mentioned reasons (Eliáš jun. et al. 2003, 2008, 2010). However, the rapid decrease of Hordeum geniculatum sites was found in period after year 2000. We believe that this significant decrease was caused by the restructuring of agriculture after the collapse of communism in 1989 (Kuzma 2000). While relatively intensive grazing of sheep and cattle took place at Hordeum geniculatum localities in the seventies and eighties (Svobodová \& Řehořek 1992), the pastures were abandoned in the nineties. Hordeum geniculatum is very competitively weak species and it can survive only temporarily on disturbed sites (e.g. rural roads) in case the grazing is not present. Gradually, the occurrence of the species disappears quickly at these sites under pressure of stronger competitors (Dítě, Eliáš jun. \& Sádovský 2003 ined.). On the other hand, we observed relatively abundant occurrence of the species if the grazing was restored in the Akomán farmstead. It is therefore possible that Hordeum geniculatum can be found on other localities in the future.

Finally, the status of the species in Slovak Red List of rare and endangered species has been reevaluated in the light of our field data. Feráková et al. (2001) included the species in the category "critically endangered" (CR). We propose to include it in the category "endangered" EN B2b(ii, iii, v)c(iii, iv) under the IUCN criteria (2001). Rescue cultivation takes place in the Botanical Garden Slovak University of Agriculture and seeds are stored in the Gene Bank of the Slovak Republic since 2009.

\section{ACKNOWLEDGEMENTS}

We are indebted to Marek Sádovský (Úlany nad Žitavou) for help with field research and Zuzana Melečková (Institute of Botany, Bratislava) for language revision. We also thank to Renata Grošaftová (Česká Lípa, Czech Republic) for the drawings and to Dušan Senko (Institute of
Botany, Bratislava) for map construction. The paper was supported by the Slovak Grant Agency for Science VEGA (grants No. 1/0814/09, 2/0030/09 and 2/003/2012) and KEGA (grant No. 3/7356/09).

\section{REFERENCES}

Borhidi, A. 1996: Magyarország Növénytársulásai. Akadémiai Kiadó, Budapest, 610 pp.

Dítě, D., Eliášs, P. jun. \& Sádovský, M. 2008: Camphorosmetum annuae Rapaics ex Soó 1933 - vanishing plant community of saline habitats in Slovakia. Thaiszia - Journal of Botany 18: 9-20.

Dítě, D., Eliáš jun., P. \& Šuvada, R., 2009: The current distribution and status of community Puccinellietum limosae in Slovakia. Thaiszia Journal of Botany 19: 63-70.

Dostál, J. \& Červenka, M. 1992: Vel'ký klúč na určovanie vyšších vyšších rastlín II. Slovenské pedagogické nakladatel'stvo, Bratislava, 1561 pp.

Eliáš, P. ml., Dítě, D. \& Sádovský, M., 2003: Rastie Acorellus pannonicus (Jacq.) Palla na Slovensku? Ochrana Prírody 22: 79-81.

Eliáš P. jun., Dítě D., Grulich V. \& Šuvada R. 2008: Occurence of Camphorosma annua Pall. in Slovakia: past and present. Flora Pannonica 6: 117-126.

Eliáš P. jun., Dítě D., Grulich V. \& Šuvada R. 2010: Revision of historical and current distribution of Pholiurus pannonicus (Host.) Trin. in Slovakia. Hacquetia 9: 177-183.

Fehér, A. 2007: Origin and development of the salt steppes and marshes in SW Slovakia. Flora Pannonica 5: 67-94.

Feráková, V., Maglocký, Š. \& Marhold, K. 2001: Červený zoznam paprad'orastov a semenných rastlín Slovenska. Ochrana prírody 10 (Supl.): 48-81.

Futák, J. 1980: Fytogeografické členenie SSR (1: 1 000 000). In: Mazúr E. (ed.): Atlas Slovenskej socialistickej republiky. Bratislava, p. 81.

Fischer, M. A., Adler, W. \& Oswald, K. 2008. Exkursionsflora für Österreich, Liechtenstein und Südtirol. Oberösterreichisches Landesmuseum Linz, pp. 1380.

Grulich, V. 1987: Slanomilné rostliny na jižní Moravě. Okresní výbor Českého svazu ochránců prírody, Břeclav, p. 76.

Grulich, V. \& Maglocký, Š. 1999: Hordeum geniculatum All. In: Čeřovský, J., Feráková, V., 
Holub, J., Maglocký, Š. \& Procházka, F. (eds.): Červená kniha ohrozených a vzácnych druhov rastlín a živočíchov SR a ČR. Vol. 5. Vyššie rastliny. Príroda, Bratislava, p. 188.

Holmgren, P.K., Holmgren, N.H. \& Barnett, L.C. (eds.) 1990: Index Herbariorum. Vol. 1: The herbaria of the World, Ed. 8. New York, 693 pp.

IUCN 2001: IUCN Red List Categories and Criteria: Version 3.1. IUCN Species Survival Commission. IUCN, Gland, Switzerland and Cambridge, UK, ii + 30 pp.

Király, G. (ed.) 2007: Vörös Lista. A magyarországi edényes flóra veszélyeztetett fajai. Saját kiadás, Sopron, $73 \mathrm{pp}$.

Krist, V. 1940: Halofytní vegetace jihozápadního Slovenska a severní části Malé Uherské nížiny. Práce moravské př́rodovědecké společnosti (Brno) 12/10: 1-100.

Kuzma, F. 2000: Zmeny štruktúry polnohospodárskej výroby na Slovensku. Zborník z MVD 2000, Slovenská polnohospodárska univerzita, Nitra, p. 105-11.

Marhold, K. \& Hindák, F. (eds.) 1998: Zoznam nižších a vyšších rastlín Slovenska. Veda, Bratislava, 687 pp.

Molnár, Zs. \& Borhidi, A. 2003: Hungarian alkali vegetation: Origins, landscape history, syntaxonomy, conservation. Phytocoenologia 33: 377-408.

Mucina, L. 1993: Puccinellio-Salicornietea. In: Mucina L., Grabherr G. \& Ellmauer T. (eds.): Die Pflanzengesellschaften Österreichs. Teil 1, Anthropogene Vegetation. Fischer, Stuttgart \& New York, pp. 522-549.

Niklfeld, H. \& Schratt-Ehrendorfer, L. 1999: Rote Liste gefährdeter Farn- und Blütenpflanzen (Pteridophyta und Spermatophyta) Österreichs. 2. Fassung. In: Niklfeld, H. (ed.): Rote Listen gefährdeter Pflanzen Österreichs, ed. 2, Grüne Reihe des Bundesministerium für Umwelt, Jugend und Familie, Wien, pp. 33-151.

Nikolić, T. \& Topić, J. (eds.) (2004): Vascular flora. - In: Čivić, K., Hršak, V., Maričević, A., Radović, J., Rajčić, A., Štefan, A., Štrbenac, A. and Topić, R. (2004): Red list of threatened plants and animals of Croatia. State Institute for Nature Protection, Zagreb, 693 pp.

Oltean, M., Negrean, G., Popescu, O., Roman, N., Dihoru, G., Sanda, V. \& Mihăilescu, S. 1994: Lista Roşie a Plantelor Superioare din România. Romanian Academy of Sciences, Institute of Biology, Bucharest, 52 pp.
Pop, I. 2002: Vegetatia solurior saraturoase den Romania. Contributi Botanice, Cluj, 35(2): 287-332.

Popescu, A. 2005: Pajişti ponto-panonice de Hordeum hystrix. In: Doniłă N., Popescu A., PaucăComănescu M., Mihăilescu S. \& Biris, I.A.: Habitatele din România. Edit. Tehnică Silvică, Bucuresti, p. 53.

Sádovský, M. 2003: Hordeum geniculatum [Report]. In: Mráz, P. (ed.): Zaujímavejšie floristické nálezy. Bulletin Slovenskej botanickej spoločnosti, Bratislava, 25: 252.

Sádovský, M., Eliáš, P. ml. \& Dítě, D. 2004: Poznámky $\mathrm{k}$ rozšíreniu a cenológii vybraných druhov halofilných rastlín na juhozápadnom Slovensku. Bulletin Slovenskej botanickej spoločnosti, Bratislava, Supl. 10: 122-126.

Stevanović, V., Jovanović S., Lakušić, D., Tomović, G. \& Niketić, M. 2006: Ugrožene biljke Srbije (priručnik o zaštiti retkih i ugroženih biljaka). Biološki fakultet IP NNK Internacional, Beograd, 95 pp.

Svobodová, Z. \& Řehořek, V. 1985: Súčasný stav flóry a vegetácie Štátnej prírodnej rezervácie Kamenínske slanisko a problematika jeho ochrany. Spravodaj oblastného Podunajského múzea, Komárno, Scientia Naturale, 5: 67-74.

Svobodová, Z. \& Řehořek, V. 1992: Príspevok k flóre slanísk Podunajskej nížiny. Spravodaj oblastného Podunajského múzea, Komárno, Scientia Naturale, 10: 49-69.

Trávníček, B. 1996: Příspěvek k rozšíření některých ohrožených a zajímavých taxonů slovenské flóry. Bulletin Slovenskej botanickej spoločnosti 18: 66-76.

Tzonev, R. T., Dimitrov, M. A. \& Roussakova, V. H. 2009: Syntaxa according to the Braun-Blanquet approach in Bulgaria. Phytologia Balcanica 15 (2): 209-233.

Vicherek, J. 1973: Die Pflanzengsellschaften der Halophyten und Subhalophytenvegetation der Tschechoslowakei. Vegetace ČSSR, ser. A, Praha, 5: 79-90.

Vozárová, M. \& Sutorý, K. 2001: Index herbariorum Reipublicae bohemicae et Reipublicae slovacae. Zprávy České Botanické Společnosti (Praha) 36, Př́loha 2001/1 \& Bulletin Slovenskej botanickej spoločnosti, Suppl. 7, 95 pp.

Received 17. 8. 2011

Revision received 10. 4. 2012

Accepted 12. 4. 2012 


\section{APPENDIX}

A list of localities of Hordeum geniculatum in Slovakia [numbers of phytogeographical regions according to Futák (1980)].

Pannonicum: 6. Podunajská nížina Lowland. Bratislava, part Petržalka - Háje, near small pond along the road around old gamekeepers house (Májovský 1985 SLO). - Bratislava, part Ovsište (Májovský 1956 SLO). - Bratislava, part Vajnory, margin of football playground $\mathrm{N}$ from the Čierna Voda settlement (Trávníček 1988 OL; Trávníček 1996). - Horná Králová (Sádovský 2003) - Močenok, Siky farmstead (Valenta 1939 BRA; Krist 1937 BRNU; Krist 1940; Pospísil 1950 SAV; Šourek 1950 BRA, PR; Grulich 1988 MMI; Svobodová 1992 NI; J. Koštál 1992 NI; Sádovský 2003; Ducháček 2007 PR; Eliáš jun., Dítě et Šuvada 2008 NI) = Cabaj-Čápor, Sik farmstead (Vlach 1935 PRG). - Šal'a, saline pastures north from the town (Klokner 1955 SLO). - Horný Jatov, Čierny vŕšok site (Dostál 1953 PR; Dostál 1955 PRC; Mladý 1959 PRC; Osvačilová 1953 NI; Grulich 1988 MMI). - Tvrdošovce, Bačala farmstead (Krist 1937 BRNU; Krist 1938 BRA and 1940). - Tvrdošovce (Scheffer 1923 BRA;
Krist 1936 BRNU, MZ, NI, PR, PRC, SLO, ZV and 1940; Skřivánek 1949 BRA; Šmarda 1949 PR; Šourek 1949 PR). =? Tvrdošovce, north-western edge of the village (Grulich 1987 MMI; Eliáš jun., Dítě et Sádovský 2003 NI; Eliáš jun. 2005 NI). = Tvrdošovce, on the playground cca 400 $\mathrm{m}$ north from the train stop, $115 \mathrm{~m}$ (Ekrt 2005 MJ). = Tvrdošovce, near the train lines (Chytrý 1994 BRNU). - Tvrdošovce, salt steppe $1 \mathrm{~km}$ north from the train stop (Grulich $1987 \mathrm{MMI}$ ). - Tvrdošovce, in surrounding of the Ráczovo jazierko Pool (Grulich 1987 MMI; Eliáš jun. 2009 NI). - Palárikovo, near the train lines to Tvrdošovce (Součková 1952 BRA; Manica 1960 ZV). =? Palárikovo, near the train stop (Dvořák 1960 BRA). =? Palárikovo, $130 \mathrm{~m}$ a. s. l. (Futák 1949 SAV, SLO; Hejný 1953 PR; Dostál 1968 PR; Dvořák 1978 OLM). - Palárikovo, 1 km southwest from the train stop (Krist 1937 BRNU; Krist 1940; Grulich 1988 MMI). - Palárikovo, Vel'ké Čiky farmstead (Smejkal 1965 BRNU). - Šurany, Čiastka gamekeeper's house (Krist 1940). Šurany, Akomáň farmstead (Krist 1940; Grulich 1987, 1988 MMI; Sádovský 2003; Eliáš jun., Dítě et Melečková 2010 NI). - Kamenín (Májovský 1957 SLO). 